KS. PAWEŁ KALETA

Wydział Prawa, Prawa Kanonicznego i Administracji

Katolickiego Uniwersytetu Lubelskiego Jana Pawła II w Lublinie ORCID: 0000-0001-6159-0997

\title{
AKTY ALIENACJI I TRANSAKCJI \\ W INSTYTUTACH ŻYCIA KONSEKROWANEGO I STOWARZYSZENIACH ŻYCIA APOSTOLSKIEGO
}

Treść: Wstęp. - 1. Pojęcie alienacji. - 2. Przedmiot alienacji w instytutach zakonnych. - 3. Wymagania prawne dokonania aktu alienacji. - 3.1. Do ważności aktu. - 3.2. Do godziwości aktu. - 4. Transakcje, które mogą pogorszyć stan majątkowy osoby prawnej. - 4.1. Zaciągnięcie kredytu 4.2. Zawarcie umowy dzierżawy. - 4.3. Dysponowanie majątkiem pod tytułem darmowym. - Wnioski.

\section{Wstęp}

Zarówno akty alienacji, jak i transakcji, które mogą pogorszyć stan majątkowy kościelnej osoby prawnej, wymagają większej rozwagi w ich wykonywaniu. Niedostateczne przygotowanie teoretyczne, jak i brak rozeznania skutków ekonomicznych spowodowanych alienacją mogą stać się przyczyną wielu trudności w utrzymaniu instytutów zakonnych. Akty alienacji i transakcji w kanonicznym systemie prawnym zostały określone w kan. 1291-1294 Kodeksu Prawa Kanonicznego z 1983 r. ${ }^{1}$, dla instytutów zakonnych w kan. $638 \$ 3$, natomiast dla instytutów świeckich w kan. 718, dla stowarzyszeń życia apostolskiego

\footnotetext{
${ }^{1}$ Codex Iuris Canonici auctoritate Ioannis Pauli PP. II promulgatus, AAS 75 (1983), II, pp. 1-317; Kodeks Prawa Kanonicznego, przekład polski zatwierdzony przez Konferencję Episkopatu, Poznań 1984 [dalej cyt. KPK/83].
} 
w kan. $741 \$ 1$. Treść tych regulacji stanie się przedmiotem niniejszego opracowania, uwzględniając dyspozycje prawne Kongregacji Instytutów Życia Konsekrowanego i Stowarzyszeń Życia Apostolskiego², w dziele pod tytułem Ekonomia w służbie charyzmatu i misji $i^{3}$ Publikacja tego dzieła miała na celu ukazanie podstawowych kryteriów działań ekonomicznych oraz zapoznanie się z procedurą dokonania aktów alienacji i transakcji podejmowanych przez przełożonych instytutów zakonnych, którzy zobowiązani są uzyskać zezwolenie na dokonanie aktu alienacji od Stolicy Apostolskiej.

\section{Pojęcie alienacji}

Pojęcie alienacji (łac. alienatione) wywodzi się z prawa rzymskiego i oznacza przeniesienie lub pozbycie się prawa własności ${ }^{4}$. W prawie kanonicznym alienacja oznacza przeniesienie prawa własności (łac. dominium directum) $\mathrm{z}$ jednego podmiotu na drugi, tak tytułem darowizny, sprzedaży, jak i zamiany. Czy to z parafii na diecezję, czy $\mathrm{z}$ domu zakonnego na prowincję ${ }^{6}$. W sytuacji, gdy nie ma przeniesienia prawa własności, na inną osobę prawną lub fizyczną, nie można mówić o alienacji ${ }^{7}$. Podobnie jest w przypadku kradzieży lub utraty dóbr na skutek przemocy ${ }^{8}$.

\footnotetext{
${ }^{2}$ Dalej cyt. Kongregacja.

${ }^{3}$ Kongregacja Instytutów Życia Konsekrowanego i Stowarzyszeń ŻyCiA Apostolskiego, Ekonomia w służbie charyzmatu i misji. Ukierunkowania, Wydawnictwo Ojców Franciszkanów, Niepokalanów 2019.

${ }^{4}$ E. Kowalczy , Zakaz alienacji, Prawo Kanoniczne 55 (2012) nr 2, s. 105.

${ }^{5}$ F. Grazian, La nozione di amministrazione e di alienazione nel Codice di diritto canonico, Roma 2002, s. 173.

${ }^{6}$ Kongregacja zwraca uwagę, aby instytut zakonny ustalił normy dotyczące równego podziału dóbr wewnątrz niego w służbie celów apostolskich (Ukierunkowania 71). Prawo własne instytutu na mocy kan. $635 \$ 2$, może uznać, że przeniesienie dóbr $\mathrm{z}$ domu zakonnego na prowincję nie jest alienacją.

${ }^{7}$ Zob. E. D’Auria, Alienation of Temporal Goods in Roman Catholic Canon Law. A Potential for Conflict, Ecclesiastical Law Journal 12 (2010), s. 33-52.

${ }^{8}$ S. Dubiel, P. Kaleta, Alienacja, w: Leksykon Prawa Kanonicznego, red. M. Sitarz, Lublin 2019, kol. 105.
} 
Ustawodawca w kan. 1254 stanowi, że alienacja jest prawem Kościoła, które wynika z ius nativum ${ }^{9}$. Oznacza to, że tego prawa nie nadaje władza państwowa, lecz wynika ono z prawa naturalnego, które przysługuje Kościołowi. Prawo to powinno być chronione i zapewnione na mocy ustaw państwowych (DH 7). W sytuacji instytutów zakonnych prawo do alienacji dóbr kościelnych wynika z przyznanej im osobowości prawnej. Zgodnie z kan. $634 \$ 1$ „Instytuty, prowincje i domy zakonne, jako osoby prawne na mocy samego prawa, zdolne są do nabywania, posiadania i alienowania dóbr doczesnych" (dla stowarzyszeń życia apostolskiego kan. $741 \$ 1$ ). W doktrynie prawa kanonicznego, jako akty alienacji przyjmuje się następujące czynności:

1. przeniesienie dóbr kościelnych, które zostały zgodnie z prawem określone jako patrimonium stabile (kan. 1291);

2. jakikolwiek akt, w którym majątek kościelny podlega obciążeniom wieczystym albo długoterminowym, takich jak prawo użytkowania lub służebności;

3. alienacja rzeczy kosztownych (kan. $638 \S 3$ );

4. alienacja dóbr ofiarowanych Kościołowi na podstawie ślubu (kan. $638 \$ 3$ );

5. alienacja znaczących relikwii i obrazów, które doznają wielkiej czci przez ludzi (kan. $1190 \$ \$ 2-3)^{10}$.

\section{Przedmiot alienacji w instytutach zakonnych}

Chociaż dobra doczesne instytutów zakonnych rządzą się przepisami księgi V KPK/83 (kan. $635 \$ 1$ ), to jednak przedmiot ten został inaczej sformułowany niż w kan. 1291. Ustawodawca w kan. $638 \$$ 3 wskazał, że przedmiotem alienacji w instytutach zakonnych nie

\footnotetext{
${ }^{9}$ Początkowo alienacja dóbr kościelnych była zakazana. Została wprowadzona w roku 470 konstytucją Leona i Antemiusza, a potem podtrzymana przez konstytucję Justyniana w 529 roku. Uzasadnieniem tego było przekonanie ustawodawcy, że majątek kościelny, podobnie jak sam Kościół, powinien na zawsze pozostać nienaruszony. E. KowAlczy , Zakaz alienacji dóbr kościelnych instytucji dobroczynnych w Cesarstwie Rzymskim, Prawo Kanoniczne 55 (2012) nr 2, s. 110-111.

${ }^{10}$ P. Kaleta, Prawne aspekty zarządzania dobrami kościelnymi, Lublin 2017, s. 172-173.
} 
jest majątek stały (zob. kan. 1291), lecz dobra kościelne (ruchomości i nieruchomości), które mogą ulec pogorszeniu ${ }^{11}$. Potwierdzeniem wysuniętej tezy stanowi treść nr 81 i 57 Ukierunkowań. W nr 81 wspomnianego dokumentu Kongregacja stwierdza, że przedmiotem alienacji są dobra kościelne „niezależnie od faktu czy były przypisane do majątku stałego, czy nie”. Z kolei w nr 57 Ukierunkowań, Kongregacja stanowi, że „przedmiotem alienacji są również działania, przez które publiczna osoba prawna mogłaby doznać uszczerbku”.

Oprócz dóbr kościelnych, które mogą ulec pogorszeniu, przedmiotem alienacji, zgodnie $\mathrm{z}$ kan. $638 \$ 3$ są również rzeczy darowane Kościołowi na podstawie ślubu (łac. rebus ex voto Ecclesiae donatis) oraz rzeczy kosztowne z racji historycznych i artystycznych (kan. $638 \$ 3$; $1292 \$ 2$ ). Wymogom przepisów o alienacji podlegają również relikwie ${ }^{12}$ o wielkim znaczeniu i obrazy, które uszanowane są wielką czcią ludzi (łac. populi) (kan. $1190 \$ \$ 2-3$ ). Kongregacja w nr 81 Ukierunkowań stwierdziła, że rzeczy kosztowne oraz relikwie o wielkim znaczeniu nie podlegają wycenie materialnej w formie wysokości monetarnej. Chcąc jednak dokonać ich alienacji, wymagane jest zezwolenie (łac. licentia) Kongregacji.

Warto zauważyć, że definicja rzeczy kosztownych lub drogocennych (łac. res pretiosa) nie została wyjaśniona w KPK/83. Jej definicję można znaleźć dopiero w kan. 1497 \$ 2 Kodeksu Prawa Kanonicznego z 1917 r.13, w którym ustawodawca wskazał, że rzeczy kosztowne cechują się istotną wartością artystyczną lub historyczną, lub materialną. Zgodnie z kan. $6 \$ 2$ : „Jeśli kanony niniejszego Kodeksu zawierają stare prawo, powinny być ocenione (łac. aestimo) z uwzględnieniem również kanonicznej tradycji”. Problem pojawia się jednak w tym, że

${ }^{11}$ F.G. Morrisey, Temporal Goods and Their Administration, w: Commentary on the Code of Canon Law, red. Á. Marzoa, J. Miras, R. Rodrígues-Ocaña, t. II, Chicago 2004, s. 1662-1671.

${ }^{12}$ Zob. L. Fiejdasz-Buczek, Relikwie, w: Leksykon Prawa Kanonicznego, red. M. Sitarz, Lublin 2019, kol. 2492-2499.

${ }^{13}$ Codex Iuris Canonici auctoritate Pii X Pontificis Maximi iussu digestus, Benedicti Papae XV auctoritate promulgatus (27.05.1917), AAS 9 (1917), pars II, pp. 2-523 [dalej cyt. KPK/17]. 
ustawodawca w kan. $638 \$ 3$ i $1292 \$ 2$ nie odwołuje się do wartości materialnych, lecz do wartości artystycznych lub historycznych. Przykładem ilustrującym może być papieski pas, na którym znajduje się krew św. Jana Pawła II. Pas ten nie ma znaczącej wartości materialnej, ale ma wartość historyczną. Z drugiej jednak strony, rzeczy kosztowne mogą mieć dodaną wartość materialną, czego przykładem może być złoto lub szlachetne kamienie, z których składa się rzecz kosztowna. Dlatego treść kan. $1497 \$ 2$ KPK/17, w którym zawarta została definicja rzeczy kosztownych, należy uznać za właściwą ${ }^{14}$.

Z kolei pojęcie rzeczy darowanych Kościołowi na podstawie ślubu (łac. rebus ex voto Ecclesiae donatis), wbrew literalnemu brzmieniu nie oznaczają każdej rzeczy przekazanej Kościołowi na podstawie aktu darowizny czy realizacji złożonego uprzednio przyrzeczenia publicznego. Chodzi więc o „dary wotywne”, czyli jak orzekła (14.01.1922) Święta Kongregacja Soboru, są to przedmioty złożone na ołtarzu lub na poświęconym obrazie, o ile nic innego nie wskazuje na przeciwną wolę darczyńcy ${ }^{15}$. Wydaje się słuszne, aby dary wotywne złożone na podstawie ślubu interpretować w kryteriach artystycznych i historycznych. W przeciwnym razie każdy dar codziennego użytku, który został złożony na ołtarzu (np. różaniec, kule inwalidzkie), będzie wymagał zezwolenia Stolicy Apostolskiej w celu ich alienacji.

Odnośnie do alienacji relikwii ${ }^{16} \mathrm{i}$ innych przedmiotów doznających czci ze strony ludzi wymagane jest zezwolenie Stolicy Apostolskiej.

\footnotetext{
${ }^{14}$ P. Kaleta, Komentarz do Kodeksu Prawa Kanonicznego Tom IV/1. Księga V. Dobra doczesne Kościoła, Poznań 2019, s. 44.

${ }^{15}$ Sacra Congregatio Concilit, Lauden. Circa donaria votiva et alienationes (14.01.1922), AAS 14 (1922), pp. 160-161.

${ }^{16}$ Pojęcie „relikwii” nie jest nazwą własną ani też pojęciem definiowanym w KPK/83. W istocie składa się z wielu różnych określeń. W ścisłym tego słowa znaczeniu, pojęcie relikwii oznacza śmiertelne szczątki osób świętych, z szacunkiem przechowywane przez Kościół, przedmioty, które do osób tych należały (a zatem relikwie ex ossibus, ex corpores, ex indumentis). W znaczeniu szerokim i potocznym „relikwiami” są również przedmioty otarte o groby świętych, oleje, lniane płótna (brandea), a także czczone wizerunki świętych. K. RAHner, H. Vorgrimrel, Mały słownik teologiczny, Warszawa 1987, kol. 391.
} 
Warto zauważyć, że ustawodawca w kan. $1190 \$ 1$ wskazuje tylko na jedną formę alienacji - sprzedaży. Z kolei w kan. $1190 \$ 2$ ustawodawca stanowi, że w przypadku znacznych relikwii lub innych doznających wielkiej czci ze strony ludzi ich alienacja (z wyjątkiem sprzedaży) jest dopuszczalna, jednakże dla ważności aktu wymagane jest zezwolenie Stolicy Apostolskiej. Zezwolenie jest również wymagane w przypadku przenoszenia tego rodzaju relikwii na stałe ${ }^{17}$.

\section{Wymagania prawne dokonania aktu alienacji}

Kongregacja podkreśla, że akt alienacji należy wykonywać w spójności z planem charyzmatycznym instytutu. Ponadto prawo własne instytutu powinno określić procedurę dla ważnego dokonania aktu alienacji, czyli sprzedaży, zamiany lub darowizny dóbr kościelnych zgodnie z prawem kanonicznym (Ukierunkowania 80 ). Analiza przepisów KPK/83 pozwala wyodrębnić wymogi prawne dotyczące ważności i godziwości aktu alienacji.

\subsection{Do ważności aktu}

Odwołując się do kan. $638 \$ 3$ oraz kan. 1291-1294 można wskazać na następujące wymagania prawne w celu ważnego dokonania aktu alienacji dóbr kościelnych:

1. pisemne zezwolenie kompetentnego przełożonego (kan. 638 $\$ 3$, por. kan. 1291);

2. uzyskanie zgody jego rady (kan. $638 \$ 3$ );

3. wskazanie, czy alienowana rzecz jest podzielna oraz wyszczególnienie rzeczy już wcześniej alienowanych (kan. $1292 \$ 3$ );

4. zezwolenie (łac. licentia) Stolicy Apostolskiej, gdy wartość dóbr alienowanych przekracza kwotę alienacji określoną przez konferencję biskupów danego kraju lub gdy przedmiotem alienacji jest rzecz drogocenna ze względów artystycznych i historycznych lub gdy jest to rzecz darowana Kościołowi

\footnotetext{
${ }^{17}$ Congregatio de Causis Sanctorum, Instructio ad peragendas inquisitiones dioecesanas vel eparchiales de causis sanctorum «Sanctorum Mater» (17.05.2007), AAS 99 (2007), pp. 465-510.
} 
na podstawie ślubu (kan. $638 § 3$ ) lub gdy są to relikwie (kan. $1190 \$ 1-2)$.

Prośbę do Kongregacji w sprawie przeprowadzenia aktu alienacji składa przełożony generalny za zgodą (łac. consensus) własnej rady (kan. 627). Prośba powinna wyrażać słuszną przyczynę, określać formy, w jakich zostanie zainwestowany zysk oraz zawierać dokumentację rzeczoznawcy (Ukierunkowania 81). Do prośby należy dołączyć również poświadczony odpis z protokołu posiedzenia rady generalnej, która udzieliła zgody na alienację. W protokole zaś należy wskazać istnienie quorum, które zgodnie $\mathrm{z}$ kan. $127 \S 1$ jest wymagane do ważności aktu administracyjnego ${ }^{18}$.

W zakresie spraw ekonomicznych każdy przełożony powinien mieć własną radę (kan. 627; 1280). Ustawodawca w kan. $638 \$ 3$ stanowi, że w celu dokonania aktu alienacji przełożony zobowiązany jest uzyskać zgodę swojej rady. W zależności od struktur organizacyjnych instytutu zakonnego przez frazę „własna rada” (łac. proprium concilium) należy rozumieć radę prowincjalną, a w przypadku przełożonego generalnego - radę generalną (kan. $627 \$ 1$ ). Warto jednak zaznaczyć, że zgodnie z dyspozycją zawartą w kan. 127, kolegium osób wydaje ważnie zgodę bezwzględną większością tych, którzy są obecni. Brak zatem wspomnianej bezwzględnej większości głosów powoduje, że akt jest nieważny, a wyższy przełożony nie może dalej procedować aktu alienacji. Zgoda udzielona przez jego radę jest wiążąca a próba podjęcia decyzji bez uzyskania zgody jego rady czyni akt nieważny ${ }^{19}$. Ustawodawca nakłada na kolegium osób biorących udział $\mathrm{w}$ akcie alienacji, aby zapoznały się ze stanem materialnym osoby prawnej przed wydaniem zgody. „Ci, którzy winni mieć udział w alienowaniu dóbr przez wyrażenie zdania lub zgody, nie powinni

\footnotetext{
${ }^{18}$ W. Adamczewski, Elementy prawa kanonicznego ze szczególnym uwzględnieniem kościelnej osoby prawnej w obrocie prawnym, Nowy Przegląd Notarialny 9 (2007) nr 3, s. 17.

${ }^{19} \mathrm{G}$. DzIERżon, Założenia generalne dotyczace aktu przełożonego kościelnego wymagającego współudziału organów partycypacji (kan. 127 par. 1 KPK), „Studia Redemptorystowskie" 11 (2013), s. 377.
} 
wyrażać zdania lub zgody, dopóki nie zapoznają się dokładnie ze stanem materialnym osoby prawnej, której dobra mają być alienowane, jak również z alienacjami już dokonanymi” (kan. $1292 \$ 4$ ). Dlatego rada prowinacjalna lub generalna (w zależności od tego, na jakim etapie jest wniosek procedowany) najpierw powinna zbadać prawo własności dóbr, czy rzecz alienowana jest podzielna; czy w prośbie o zezwolenie na alienację zostały wyszczególnione części już wcześniej alienowane (kan. $1292 \$ 3-4)^{20}$. Obowiązek dostarczenia pełnej dokumentacji o sytuacji ekonomicznej osoby prawnej spoczywa na zarządcy dóbr, których dobra mają być alienowane. Uzupełnienie wymogu zapoznania się ze stanem ekonomicznym osoby prawnej stanowi kan. 127 \$3, który brzmi: „Wszyscy, których zgoda jest wymagana, zobowiązani są szczerze wyrazić swoje stanowisko, a także, gdy domaga się tego ważność sprawy, stanowczo zachować tajemnicę".

Gdy wartość rzeczy alienowaej lub transakcji nie przekracza maksymalnej kwoty przewidzianej dla alienacji, nie oznacza to, że zarządca dóbr kościelnych może nimi zarządzać dobrowolnie, według własnego uznania. Wówczas zezwolenia na alienację lub transakcję udziela wyższy przełożony za zgodą jego rady. Nie ma zatem wymogu uzyskania zezwolenia od Stolicy Apostolskiej.

Trzecim wymogiem do ważności dokonania aktu alienacji jest wskazanie czy alienowana rzecz jest podzielna oraz wyszczególnienie części rzeczy już wcześniej alienowanych (kan. 1292 \$3; Ukierunkowania 81). Przepis ten ma na celu zapobieżenie stopniowego alienowania całej rzeczy podzielnej bez zezwolenia kompetentnej władzy. Niezachowanie tego wymogu, zgodnie z kan. $1292 \$ 3$, skutkuje nieważnością udzielonej zgody na alienację. Analogiczną zasadę należy stosować w sytuacji jednoczesnego alienowania wielu dóbr. Reguły tej nie zawiera wprawdzie expressis verbis kan. $1292 \$ 3$ jednakże dyrektywy w tym zakresie zostały zawarte w odpowiedzi Papieskiej Komisji dla Autentycznej Interpretacji Kodeksu Prawa Kanonicznego

\footnotetext{
${ }^{20}$ M. Sitarz, Kompetencje organów kolegialnych $w$ Kościele partykularnym $w$ sprawowaniu władzy wykonawczej według Kodeksu Prawa Kanonicznego z 1983 roku, Lublin 2008, s. 198.
} 
z 20 lipca 1929 r. ${ }^{21}$, z której wynika, że w przypadku jednoczesnych alienacji różnych dóbr tego samego podmiotu, należy dokonać zsumowania poszczególnych wartości alienacji i na podstawie tak ustalonej wartości łącznej należy określić wartość przedmiotu alienacji. Reguła ta w założeniu swym ma na celu wykluczenie ewentualnych prób pomniejszania rzeczywistej wartości alienacji i pomijania w ten sposób wymaganego zezwolenia Stolicy Świętej.

$\mathrm{W}$ analizowanym dokumencie Kongregacja wskazała, że rozpatrywane są przez nią wnioski o alienację, gdy wartość dóbr alienowanych przekracza najwyższą sumę alienacji określoną przez konferencję biskupów (Ukierunkowania 57). W Polsce Konferencja Episkopatu Polski w 2007 r. określiła 1.000.000 € jako summa maxima alienacji ${ }^{22}$. Należy zauważyć zaistniałą nieścisłość, ustawodawca bowiem w kan. $638 § 3$ przewiduje, że kwotę alienacji określa Stolica Apostolska. Zgodnie z Konstytucją Apostolską Pastor Bonus ${ }^{23}$ dla instytutów życia konsekrowanego i stowarzyszeń życia apostolskiego kompetencje te ma Kongregacja ds. Instytutów Życia Konsekrowanego i Stowarzyszeń Życia Apostolskiego (PB art. 73). W praktyce jednak dykasteria przyjęła maksymalną kwotę alienacji nieokreśloną przez nią, lecz przez konferencję biskupów dla danego kraju (Ukierunkowania 57).

W przypadku gdy przedmiotem alienacji jest rzecz drogocenna ze względów artystycznych i historycznych lub gdy jest to rzecz darowana Kościołowi na podstawie ślubu (kan. $638 \$ 3$ ) lub gdy są to relikwie (kan. $1190 \$ 1-2)$ Kongregacja rozpatruje te wnioski, nie ma jednak wymogu określenia ich wartości monetarnej (Ukierunkowania 82).

\footnotetext{
${ }^{21}$ Pontifica Commissio ad Codicis Camotes Authentice Interpretandos, De alienatione bonorum ecclesiasticorum, AAS 21 (1929), s. 574.

${ }^{22}$ Zob. Kongregacja do sPRAw Biskupów, Dekret $z$ dnia 05 grudnia 2006 roku zawierajacy recognitio decyzji Konferencji Episkopatu Polski w sprawie nowych sum (minimalnej i maksymalnej) w związku z alienacją dóbr kościelnych, Akta Konferencji Episkopatu Polski (2007) nr 13, s. 33.

${ }^{23}$ Sanctus Ionnnes Paulus PP. II, Constitutio apostolica de Romana Curia «Pastor bonus» (28.06.1988), AAS 80 (1988), s. 841-912; tekst polski w: Kodeks Prawa Kanonicznego. Komentarz, red. P. Majer, Kraków 2011, s. 1397-1465 [dalej cyt. PB]
} 
Warto zauważyć, że wymagane zezwolenie Stolicy Apostolskiej do aktu alienacji nie przenosi odpowiedzialności na Kongregację. Jak wyjaśniła Papieska Rada ds. Interpretacji Tekstów Prawnych, wydanie zezwolenia jest jedynie gwarancją, że działanie takie jest zgodne z przeznaczeniem majątku kościelnego. Stanowi ono akt władzy administracyjnej mającej na celu zapewnienie dobrego użytkowania dóbr publicznych należących do osób prawnych w Kościele ${ }^{24}$. Zezwolenie Stolicy Apostolskiej na alienację dóbr kościelnych może być udzielone (jeśli to jest konieczne z uwagi np. na ryzyko powstania szkody związanej z opóźnieniem) także przez legata papieskiego, jeśli suma alienacji nie przekracza podwójnej wysokości maksymalnej kwoty alienacji ${ }^{25}$.

\subsection{Do godziwości aktu}

Wymagania prawne dotyczące godziwości aktu zostały określone w kan. 1293. Do nich należą:

1. słuszna przyczyna;

2. pisemna wycena rzeczy alienowanej;

3. zachowanie innych środków ostrożności przepisanych przez uprawnioną władzę.

Pierwszym dokumentem wymaganym przez Kongregację w celu wydania zezwolenia na alienację jest prośba, którą składa przełożony generalny za zgodą własnej rady. We wniosku tenże powinien przedstawić słuszną przyczynę (łac. iusta causa) dokonania aktu alienacji (kan. $1293 \$ 1,1^{\circ}$ ) i określić formy, w jakich zostanie zainwestowany zysk (kan. $1294 \$ 2$ ). Wśród słusznych przyczyn ustawodawca wymienia: naglącą konieczność, wyraźną korzyść, pobożność, miłość lub inną poważną rację pasterską. Kongregacja nie zezwala na sprzedaż mającą na celu zaradzenie nagłym potrzebom finansowym bez

\footnotetext{
${ }^{24}$ Pontificio Consiglio Per i Testi Legislativi, Nota Esplicativa «La funzione dell'autorità ecclesiastica sui beni ecclesiastici», Communicationes 36 (2004) nr 1, s. 27.

${ }^{25}$ Zob. Congregatio Pro EpIsCOPIS, Index facultatum legatis pontificiis tributarum, 1986, nr 6.
} 
uprzedniej oceny przyczyn powodujących taką konieczność (Ukierunkowania 81). Gdy alienacje są niezbędne dla spłacenia długów, które instytut zaciągnął w prowadzeniu swoich dzieł apostolskich, niezbędne jest, aby w dokumentacji został przedstawiony plan uzdrowienia ekonomiczno-finansowego (Ukierunkowania 81).

Drugim dokumentem wymaganym przez Kongregację w celu uzyskania zezwolenia jest wycena rzeczy alienowanej. W dokumencie kongregacji zauważyć można jednak pewną nieścisłość. Ustawodawca bowiem w kan. $1293 \$ 1,2^{\circ}$ wskazuje na „wycenę rzeczy alienowanej dokonanej na piśmie przez rzeczoznawców"26. Natomiast Kongregacja w Ukierunkowaniach nr 81 wskazuje na „uwierzytelnioną dokumentację rzeczoznawcy”. Z dyspozycji prawnej zawartej w kan. kan. $635 \$$ 1 należy wnioskować, że dobra doczesne instytutów zakonnych co do zasady rządzą się przepisami księgi V KPK/83. Jednakże ustawodawca w kan. $638 \$ 3$ nie przewiduje przepisów wymaganych do godziwości aktu administracyjnego. Można zatem przyjąć, że kan. $638 \$ 3$ stanowi wyjątek. Wychodząc jednak z uprawnienia zawartego w kan. $635 \$ 2$ należy stwierdzić, że każdy instytut powinien ustanowić odpowiednie normy dotyczące używania i zarządzania dobrami, w tym również wymagań co do godziwości w dokonania aktu alienacji. Warto jednak zaznaczyć, że jeśli ustawodawca w kan. $1293 \$ 1$, $2^{\circ}$ wskazuje na liczbę mnogą rzeczoznawców, wcale to jednak nie oznacza, że mają to być dwie wyceny. Nic nie stoi na przeszkodzie, aby była to jedna wycena sporządzona przez rzeczoznawcę kanonicznego, która ostatecznie została potwierdzona przez kompetentny organ cywilny ${ }^{27}$. Kongregacja w Ukierunkowaniach jasno wskazuje na „uwierzytelnioną dokumentację rzeczoznawcy”. Warto dodać, że wymóg uzyskania wyceny rzeczy alienowanej odnosi się do kan. 1294

\footnotetext{
${ }^{26} \mathrm{~W}$ komentarzach do can. $1530 \$ 1,1^{\circ} \mathrm{KPK} / 17$, jak i kan. $1293 \$ 1,2^{\circ}$ wskazuje się na dwóch rzeczoznawców. F.G. Morrisey, The Temporal Goods of the Church..., s. 735 .

${ }^{27}$ Sekretarz Kongregacji do spraw Instytutów Życia Konsekrowanego i Stowarzyszeń Życia Apostolskiego, AbP Piergiorgio Silvano Nesti C.P., Komunikat w sprawie alienacji z 21.12.2004 (Prot. N. 971/2004).
} 
$\$ 1$, według którego „Z reguły nie powinno się alienować rzeczy za kwotę mniejszą niż określoną w wycenie". W związku z tym wycena rzeczoznawców ma być podstawą do określenia wartości rzeczy alienowanej, która pozwoli stwierdzić, czy wartość rzeczy alienowanej przekracza największą kwotę alienacji określoną przez konferencję danego kraju ${ }^{28}$.

Trzecim wymogiem godziwości dokonania aktu alienacji jest zachowanie innych środków ostrożności przepisanych przez uprawnioną władzę (kan. $1293 \$ 2$ ). Kongregacja do tych środków zalicza uzyskanie opinii od ordynariusza miejsca, w którym jest usytuowana nieruchomość (Ukierunkowania 94). Dialog z biskupem diecezjalnym pokazuje, że zarządzanie dobrami to nie jest tyko sprawa instytutu życia konsekrowanego czy stowarzyszenia życia apostolskiego, ale jest „naszą sprawą” i całego naszego dziedzictwa. Chodzi więc zatem o to, aby „działać razem”, ponieważ dzieła instytutów nie są oderwane od Kościoła, ale wpisują się w realizację misji całego Kościoła. (Ukierunkowania 32). Opinia jest wymagana nie tylko w przypadku alienacji dóbr, ale również w przypadku likwidacji domu lub dzieła (kan. $616 \$ 1$ ). Wymogiem tym objęte są instytuty zakonne na prawie papieskim, natomiast od instytutów zakonnych na prawie diecezjalnym lub klasztorów sui iuris wymagane jest zezwolenie ordynariusza miejsca, w którym znajduje się nieruchomość przeznaczona na alienację (Ukierunkowania 81). Tego rodzaju porozumienie ma umożliwić ewentualne nabycie rzeczy alienowanej po tej samej cenie. Dobra kościelne nie są oddawane świeckim właścicielom, lecz nadal służą realizacji misji Kościoła.

Kongregacja ponadto zaleca, jeśli to możliwe, aby przełożeni wyżsi poinformowali o swoich zamiarach inne instytuty obecne na tym samym terenie, by danego miasta lub diecezji nie pozbawić obecności zgromadzeń zakonnych. Zaleca się także, jeśli jest to możliwe, aby dać możliwość cesji instytucjom kościelnym, unikając w każdym przypadku alienacji wpływających na dobro wspólne Kościoła

\footnotetext{
${ }^{28}$ L. Świto, Alienacja majątku kościelnego $w$ diecezjach rzymskokatolickich $w$ Polsce, Olsztyn 2010, s. 125.
} 
(Ukierunkowania 80). W sytuacji konieczności dokonania sprzedaży osobie świeckiej, w wyborze kontrahenta powinno się rozważyć jego reputację, a w przypadku płatności w ratach pozyskać odpowiednie gwarancje, najlepiej ze źródła bankowego lub ubezpieczeniowego. W przyznawaniu obowiązków lub mandatów do sprzedaży, realizowanych $\mathrm{w}$ formie pisemnej, powinno się zwrócić szczególną uwagę na wszystkie klauzule, nie pomijając, w szczególności, sprecyzowania każdego warunku, któremu ma podlegać operacja, jak również wysokość prowizji, która zostanie przyznana pośrednikowi. Tam, gdzie jest to możliwe, powinno się unikać przyznawania pełnomocnictw na wyłączność (Ukierunkowania 80).

Biorąc pod uwagę złożoność zagadnień ekonomicznych i finansowych w zarządzaniu dobrami i dziełami, w obecnych czasach prawie niemożliwe jest działanie bez współpracy ze specjalistami, osobami świeckimi lub członkami innych instytutów. Jednak w ich doborze należy dać pierwszeństwo osobom świadomym specyfiki instytutów, unikając odwoływania się do jednego tylko specjalisty (Ukierunkowani 66). Kongregacja wskazuje, aby instytuty zakonne wystrzegały się dwóch skrajności, Pierwsze to rezygnowanie z porad specjalistów, aby nie wydawać pieniędzy, powoduje to narażanie się na kłopoty prawne, ekonomiczne lub fiskalne. Drugie, to wydatkowanie pieniędzy instytutu, bez zastanowienia, na konsultacje, które nie zawsze okazują się przydatne.

Kongregacja zastrzega sobie prawo, że może wymagać podjęcia innych środków ostrożności w celu uniknięcia szkody Kościoła (Ukierunkowania 81 ).

$\mathrm{W}$ przypadku alienacji dóbr usytuowanych w Rzymie, przed wydaniem zezwolenia, Kongregacja przekazuje wniosek do Sekretariatu Stanu i Administracji Dóbr Stolicy Apostolskiej w celu zweryfikowania ich ewentualnego zainteresowania alienowanymi nieruchomościami. Natomiast gdy alienowanie nieruchomości usytuowane są na Środkowym Wschodzie, kompetentna jest Kongregacja do spraw Kościołów Wschodnich (Ukierunkowania 81).

Zgodnie z kan. 1296, gdyby dobra kościelne zostały alienowane bez zachowania formalności przepisanych prawem kościelnym, 
a alienacja byłaby ważna w świetle prawa cywilnego, do kompetentnej władzy kościelnej należy decyzja, czy należy wszcząć odpowiednie działania dla odzyskania praw Kościoła.

\section{Transakcje, które mogą pogorszyć stan majątkowy osoby prawnej}

Przez pojęcie transakcji (łac. negotium) należy rozumieć jakąkolwiek czynność prawną, która może pogorszyć stan majątkowy (łac. conditio patrimonialis) publicznej osoby prawnej. Warto zaznaczyć, że w kan. 1533 KPK/17 był zastosowany termin contractus, który wprost odnosił się do umów (dosł. kontraktów) ${ }^{29}$. W dyskusji jednak nad schematem kan. 638 postanowiono zmienić termin constractus na cuiuslibet negotium, którą należy przetłumaczyć „jakakolwiek czynność prawna”. Nie chodzi tu więc o wszystkie czynności prawne, lecz tylko te, które mogą pogorszyć conditio patrimonialis publicznej osoby prawnej ${ }^{30}$.

Kongregacja w omawianym dokumencie wskazuje na trzy przykłady transakcji, które mogą pogorszyć stan majątkowy publicznej osoby prawnej. Do nich należy zaciągnięcie kredytu, zawarcie umowy dzierżawy oraz dysponowanie pod darmowym tytułem. Należy jednak dodać, że wymienione przez Kongregacje tytuły transakcji, które mogą pogorszyć stan majątkowy kościelnej osoby prawnej, nie mają katalogu zamkniętego. Należą do nich wszelkie inne transakcje, w tym umowy nienazwane ${ }^{31}$, z zawarciem których łączy się ryzyko pogorszenia sytuacji majątkowej Kościoła. Do takich sytuacji Kongregacja włącza m.in. transakcje, które dotyczą potrzeb ubezpieczeniowych i utrzymania członków instytutu lub gdy wpisują się one

\footnotetext{
${ }^{29}$ Zob. szerzej M. OLkowicz, Problematyka umów, zwłaszcza alienacji, na podstawie Kodeksu prawa kanonicznego z 1983 roku oraz prawa polskiego, Studia Redemptorystowskie 15 (2017), s. 317-335; M. ToмкIEwICz, Obrót majątkiem Kościoła rzymskokatolickiego w Polsce, Olsztyn 2013, s. 35-42.

${ }^{30}$ P. KAletA, Prawne aspekty zarządzania dobrami kościelnymi, Lublin 2017, s. 212; J.A. Renken, Threatening Contracts. The Discipline and Application of Canon 1295, Studia Canonica 45 (2011) nr 1, s. 506.

${ }^{31} \mathrm{~Np}$. umowy o eurodotacje.
} 
w strategiczną decyzję w zakresie utrzymania, likwidacji dzieł lub $\mathrm{w}$ procedurę konkursową na zarządzanie stosunkami z wierzycielami (Ukierunkowania 98). W związku z tym enumeratywne sformułowanie wszystkich transakcji mijałoby się z celem wobec różnorodności form, jakie wraz z dynamiką zmian społeczno-ekonomicznych pojawiają się w obrocie prawnym ${ }^{32}$.

\subsection{Zaciągnięcie kredytu}

Przepisy dotyczące kredytu i pożyczek ustawodawca zawarł w kan. 639 § 5: „Przełożeni nie powinni zezwalać na zaciąganie długów, jeśli nie jest pewne, że ze zwyczajnych dochodów można spłacić należne procenty oraz w niedługim czasie, z uzyskanej zgodnie z prawem amortyzacji, zwrócić sumę podstawową”. Należy dodać, że przepis ten również stosuje się do stowarzyszeń życia apostolskiego (kan. 741 $\$ 1$ ) i do instytutów świeckich (kan. 718). Ustawodawca w kan. $639 \$ 5$ wskazuje na dwa czynniki pozwalające na ocenę wydania zezwolenia na zaciągnięcie kredytu. Pierwszym wyznacznikiem jest pewność, że ze zwyczajnych dochodów będzie można spłacić należne procenty. Takiej pewności przełożony nabiera w wyniku realnej oceny stanu posiadania oraz znajomości stałych dochodów kościelnej osoby prawnej33. Ocena nie może jednak pominąć nieprzewidzianych dochodów, gdyż te nie stanowią racjonalnej podstawy uzyskania pewności. Drugi czynnik dotyczy upewnienia się, że w niezbyt długim czasie zaciągnięty dług zostanie spłacony ${ }^{34}$. W tym kontekście Kongregacja dodaje, że do przełożonego należy ocena racjonalności prognoz, na których opierają się przychody służące do pokrycia zadłużenia

\footnotetext{
${ }^{32}$ L. Św ito, M. Toмкiewicz, Kompetencje Stolicy Apostolskiej w zakresie alienacji majątku Kościoła powszechnego w świetle Kodeksu Prawa Kanonicznego z 1983 r., w: Pecunia servire debet sed non regere. Księga Jubileuszowa dedykowana Księdzu Profesorowi Stanisławowi Dubielowi, red. K. Wiak, P. Kaleta, Lublin 2017, s. 398.

${ }^{33}$ R. Smith, Temporal Goods and Their Administration, w: New Commentary on the Code of Canon Law, red. J.P. Beal, J.A. Coriden, T.J. Green, New York 2000, s. 805.

${ }^{34}$ D.J. Andrés, El derecho de los religiosos. Comentario al Código Domingo, Madrid 1985, s. 189.
} 
(Ukierunkowania 87). Przełożony instytutu zakonnego powinien również badać całościową sytuację finansową, z uwzględnieniem planu inwestycyjnego (planowanie długoterminowe) i efektywnej stałości ekonomicznej. W sytuacji, gdy bilans konkretnej osoby prawnej lub jej przewidywany rozwój wykażą sytuację krytyczną, przełożony powinien dokonać oceny i natychmiast podjąć stosowne kroki (Ukierunkowania 87 ).

W sytuacji, gdy wartość proponowanego kredytu przekracza najwyższą kwotę alienacji określoną przez konferencję biskupów (w Polsce $1000000 €$ ), wówczas przełożony generalny za zgodą własnej rady powinien zwrócić się do Kongregacji o uzyskanie zezwolenia (Ukierunkowania 75). Do wniosku przełożony powinien dołączyć całościowy plan zadłużenia instytutu oraz jego plan spłaty (Ukierunkowania 88). Należy zaznaczyć, że zezwolenie Kongregacji jest wymagane do ważności aktu (kan. $638 \$ 3$ ). Kongregacja dodaje, że w sytuacji kryzysowej danego dzieła, nie jest udzielane zezwolenie na zaciągnięcie kredytu bez uprzedniego zbadania przyczyn powodujących trudności ekonomiczne. Podobnie jest w sytuacji znacznych sum i brak audytu Dykasteria może nie przyznawać zezwolenia (Ukierunkowania 88). Jeśli zaś wysokość proponowanego kredytu nie przekracza kwoty alienacji, zezwolenie na jej zawarcie wydaje wyższy przełożony za zgodą własnej rady.

\subsection{Zawarcie umowy dzierżawy}

Dzierżawa jest to umowa dwustronna, na mocy której wydzierżawiający zobowiązuje się oddać dzierżawcy rzecz do używania i pobierania pożytków przez czas oznaczony lub nieoznaczony, a dzierżawca zobowiązuje się płacić wydzierżawiającemu umówiony czynsz ${ }^{35}$. Przepisy dotyczące dzierżawy zostały zawarte w kan. 1297-1298. Dobra instytutów zakonnych na mocy kan. $635 \$ 1$ rządzą się przepisami księgi V KPK/83.

\footnotetext{
${ }^{35}$ P. Kaleta, Dzierżawa, w: Leksykon Prawa Kanonicznego, red. M. Sitarz, Lublin 2019, kol. 659.
} 
Konferencja biskupów danego kraju, zgodnie z kan. 1297, powinna określić normy w zakresie zawarcia umowy dzierżawy. Warto zaznaczyć, że wydana dnia 25.08.2015. Instrukcja Konferencji Episkopatu Polski w sprawie zarządzania dobrami doczesnymi Kościoła pełni jedynie funkcję vademecum, nie jest więc normą prawną wynikającą z dekretu (zob. kan. $455 \$ 1$ ). W związku z tym skuteczność wydanej instrukcji zależy od dekretów wykonawczych wydanych przez biskupa diecezjalnego ${ }^{36}$. Natomiast w instytutach zakonnych własne prawo powinno określić sposób zarządzania dobrami (kan. $635 \$$ 2). Brak w tym względzie wydanych norm prawnych przez Konferencję Biskupów lub własne prawo upoważnia zarządców dóbr kościelnych do przestrzegania przepisów prawa świeckiego, chyba że te są przeciwne prawu Bożemu lub prawo kanoniczne inaczej przewiduje (kan. 1290) ${ }^{37}$. W tym kontekście wyjątek stanowi kan. 1298, w którym ustawodawca zabrania sprzedawać lub wydzierżawiać dóbr kościelnych ich zarządcom albo ich bliskim, aż do czwartego stopnia bez specjalnego pisemnego zezwolenia właściwej władzy (Ukierunkowania 80). W instytutach zakonnych zawarcie umowy dzierżawy odnosi się do przepisu zawartego w kan. $638 \$ 3$. Kongregacja rekomenduje, że w sytuacji zawarcia umowy dzierżawy długoterminowej lub jakiejkolwiek transakcji, z której wynika ryzyko pogorszenia stanu majątkowego kościelnej osoby prawnej, wymagane jest wówczas zezwolenie wyższego przełożonego, który może go wydać dopiero po uzyskaniu zgody własnej rady. W sytuacji, gdy wartość dóbr oddawanych w dzierżawę jest większa od sumy alienacji określonej przez konferencję biskupów (w Polsce $1000000 €$ ), a czas trwania dzierżawy przekracza dziewięć lat, wymagane jest ponadto zezwolenie Kongregacji. Przy czym wniosek przekazany przez przełożonego generalnego za zgodą jego rady powinien zawierać przyczyny prośby i w załączeniu zawierać projekt umowy (Ukierunkowania 78).

\footnotetext{
${ }^{36}$ Konferencja Episkopatu Polski, Instrukcja Konferencji Episkopatu Polski w sprawie zarządzania dobrami Kościoła z dnia 25 sierpnia 2015 r. Akta Konferencji Episkopatu Polski 27 (2015), s. 140.

${ }^{37}$ A. Domaszk, Dobra doczesne Kościoła, Warszawa 2016, s. 279.
} 
Zanim jednak przełożony wyda zezwolenie, powinien sprawdzić jakość najemcy, upewnić się, że cele użytkowania dóbr są zgodne z misją instytutu i specyfiką dóbr doczesnych Kościoła i nie są zmienne w czasie, chyba że zostało to wyraźnie autoryzowane w akcie własności. Przełożony powinien upewnić, że nieruchomość jest kompatybilna z zakładanym użytkowaniem (Ukierunkowania 76). Powinien zatem właściwie ustalić stosunek dzierżawy, zwracając uwagę na sposoby formalizacji kontraktu i jego klauzule. Stosunek dzierżawy ma także przewidywać i regulować sposoby i warunki, zgodnie z którymi dobra oddane w dzierżawę będą zwracane po jego ustaniu. Przełożony powinien ocenić możliwe implikacje związane z dzierżawą, biorąc pod uwagę, że dobra te nie będą dostępne dla instytutu przez czas trwania zawartej umowy dzierżawy (Ukierunkowania 76).

\subsection{Dysponowanie majątkiem pod tytułem darmowym}

Przez pojęcie dysponowanie pod tytułem darmowym należy rozumieć oddanie dóbr kościelnych głównie nieruchomości w użytkowanie, bezczynszowe korzystanie z gruntów rolnej [potocznie nazywana dzierżawa za podatek], lub darmowe użyczenie. Kongregacja postanowiła, że w zakresie dysonowania majątkiem pod tytułem darmowym obowiązują te same przepisy co do dzierżawy. Nadto, Kongregacja podkreśla, aby przełożeni zwrócili uwagę na zobowiązania i koszty, które są związane z własnością oraz powinni rozważyć ewentualną potrzebę zabiegów restrukturyzacyjnych lub nadzwyczajnego zarządzania (Ukierunkowania 77).

\section{Wnioski}

Dokonanie aktów alienacji i transakcji wymaga wiele rozwagi. Ze względu na negatywne skutki, jakie mogą one wywołać Kongregacja do spraw Instytutów Życia Konsekrowanego w dziele pt. Ekonomia w stużbie charyzmatu i misji wprowadziła wytyczne, które mają służyć jako pomoc w praktycznym wykonaniu aktów alienacji i transakcji.

Aktom alienacji podlegają dobra kościelne niezależnie od faktu czy były przypisane do majątku stałego, czy nie. Zezwolenie kongregacji na akty alienacji lub transakcji jest wymagane gdy wartość dóbr 
alienowanych przekroczy maksymalną kwotę alienacji określoną przez konferencję biskupów danego kraju (w Polsce kwota ta wynosi $1.000 .000 €$ ). Prośbę do Kongregacji w sprawie przeprowadzenia aktu alienacji składa przełożony generalny za zgodą własnej rady. Oprócz wymogów zawartych w KPK/83, Kongregacja wprowadza wymóg przedłożenia uwierzytelnionej dokumentacji rzeczoznawcy, która określi wartość rynkową dóbr alienowanych. Kongregacja podkreśla, aby w aktach alienacji i transakcji „działać razem”, czyli przełożeni zakonni powinni wystąpić do ordynariusza miejsca, w którym jest usytuowana nieruchomość o opinię, w sprawie ewentualnego nabycia dóbr alienowanych. W sytuacji likwidacji dzieła lub domu zakonnego przełożeni wyżsi powinni poinformować o swoich zamiarach inne instytuty obecne na tym samym terenie, aby danego miasta lub diecezji nie pozbawić obecności zgromadzeń zakonnych. W celu zmniejszenia zagrożeń wynikających z alienacji lub transakcji Kongregacja zaleca, aby skorzystać ze współpracy ze specjalistami, osobami świeckimi lub członkami innych instytutów, unikając jednak konsultacji tylko $\mathrm{z}$ jednym specjalistą. Jeśli jest to możliwe, Kongregacja zaleca, aby dać możliwość pierwszeństwa nabycia rzeczy alienowanej instytucjom kościelnym.

\section{Acts of alienations and transactions in the institutes of consecrated life and associations of apostolic life}

The points explored in this study refer to the guidelines published by the Congregation for Institutes of Consecrated Life and Societies of Apostolic Life entitled Economy at the service of the charism and mission. These guidelines aim to provide guidance to administrators involved in the practical implementation of acts of alienation and transactions.

All sales exceeding the maximum amount pursuant to can. $638 \$ 3$ require the Congregation's authorization, regardless of whether the goods are ascribed to the stable patrimony. In Poland for instance, the maximum amount is $€ 1.000 .000$. Superior general should present such requests for authorization, having initially sought consent from their council. Apart from the requirement contained in the 1983 Code of Canon Law, the 
Congregation also requires the submission of a sworn assessment of the goods to be alienated. The alienation of goods is not an independent act. The Congregation emphasizes that major superiors should "act together" with the local church. Prior to submitting a request for authorization, he or she should therefore request the written opinion of the ordinary of the place where the property is located.

Those major superiors intending to proceed with the closure of a community or work, should also inform other religious institutes in the same area about their intentions. This should be done in order to ensure that the diocese does not become deprived of religious congregations. In order to reduce risks arising from alienation or transactions, the Congregation recommends collaboration with external professionals (lay people or members of other religious institutes) in order to avoid the rash recourse of engaging a single professional worker. If possible, the Congregation recommends that priority is given to church institutions to purchase these alienated goods.

SŁOWA KLUCZOWE: akty alienacji; transakcje, które mogą pogorszyć stan majątkowy osoby prawnej; dzierżawa nieruchomości; zawarcie kredytów hipotecznych.

KEYwORDS: acts of alienation; transactions which can worsen the patrimonial condition of a juridic person; a lease of buildings; credit mortgages

\section{Nota o AUTORzE}

Ks. DR hab. PAWee Kaleta, Prof. UCZelni - pracownik naukowo-dydaktyczny w Instytucie Prawa Kanonicznego Wydziału Prawa, Prawa Kanonicznego i Administracji Katolickiego Uniwersytetu Lubelskiego Jana Pawła II. 